\title{
A Legacy of Derogation: Prejudice toward Aboriginal Persons in Canada
}

\author{
Todd G. Morrison, Melanie A. Morrison, Tomas Borsa \\ Department of Psychology, University of Saskatchewan, Saskatoon, Canada \\ Email: Todd.Morrison@usask.ca, Melanie.Morrison@usask.ca, Tomas.Borsa@usask.ca
}

Received 25 May 2014; revised 3 June 2014; accepted 9 June 2014

Copyright (C) 2014 by authors and Scientific Research Publishing Inc.

This work is licensed under the Creative Commons Attribution International License (CC BY). http://creativecommons.org/licenses/by/4.0/

c) (i) Open Access

\begin{abstract}
Interpersonal prejudice toward Aboriginal men and women has, to date, received little attention from Canadian social psychologists. The present study sought to address this omission by examining the correlates of Old-Fashioned Prejudice (O-PATAS) and Modern Prejudice (M-PATAS) toward Aboriginal persons. Data from two samples (Sample 1: $n=280,71.6 \%$ females; Sample 2: $n$ $=163,70.9 \%$ females) were used. As predicted, in Sample 1, respondents evidenced greater levels of modern prejudice than old-fashioned prejudice, and both forms correlated positively with social dominance orientation, right-wing authoritarianism and negativity toward other stigmatized groups (specifically, gay men and overweight persons). For Sample 2, modern prejudice toward Aboriginal people correlated negatively with empathy as well as self-reported contact with Aboriginal people. However, no association was observed between scores on the M-PATAS and a multifaceted measure of religiosity.
\end{abstract}

Keywords

Aboriginal, Prejudice, Canada, Discrimination, Stereotypes

\section{Introduction}

It is an unfortunate reality that almost every indigenous group has suffered prejudice at the hands of a settler population (Brave Heart \& DeBruyn, 1998; Maaka \& Andersen, 2006; Pedersen \& Walker, 1998; Williams, 2012). In Canada, a two-pronged legacy of prejudice and discrimination at both the institutional and interpersonal levels has had a profound impact on the health, cultures, and languages of Aboriginal peoples (Morrison, Morrison, Harriman, \& Jewell, 2008). For much of Canada’s Pre-Confederation history, colonialist ideologies of European racial and cultural supremacy contributed to a complex and ambivalent relationship with Aboriginal peoples that vacillated between outright hostility to patronizing subordination (Moss \& Gardner O’Toole, 1991). 
Having the avowed goal of "fixing the Indian Problem” (Bartlett, 1980) through aggressive assimilation, federal policies led to widespread sedenterization, population loss, displacement, and massive social disruptions among many Aboriginal peoples (Brave Heart \& DeBruyn, 1998; Kirmayer, Tait, \& Simpson, 2009; Waldram, 2004). The legacy of Canada's colonialist past remains, as Waldram, Herring, and Young (2006) posit that Aboriginal peoples have long been considered "the most disadvantaged group in an otherwise affluent society" (p. 3). Indeed, Statistics Canada (2010) reports that, in comparison to non-Aboriginal persons, Aboriginal people in Canada are: 1) more likely to live in homes in need of major repairs (e.g., running water); 2) less likely to graduate from high school; 3) more likely to be unemployed; and 4) more likely to be the victim of a violent crime. Overall, Aboriginal people in Canada have higher incidences of poor health and lower life expectancies.

Further compounding such historically-grounded inequalities, interpersonal prejudice toward Aboriginal peoples appears to be a pervasive phenomenon (Morrison et al., 2008). Among the limited number of studies which have focused on Aboriginal peoples in Canada, Haddock, Zanna, and Esses (1994) reported that the most frequently cited descriptors of Aboriginal peoples by non-Aboriginals were "alcoholic," "lazy,” and "uneducated.” Claxton-Oldfield and Keefe (1999) found that non-Aboriginals' attitudes toward Innu were similarly negatively valenced. More recently, Morrison et al. (2008) found that a majority of participants scored above the midpoint on a measure of personal endorsement of Aboriginal stereotypes, most of which were negative in tone. Despite these exceptions, there is scant research examining prejudiced attitudes toward Aboriginal people in Canada.

The goals of the current study are to address this omission by examining various correlates of prejudice toward Aboriginal persons. In accordance with current theorizing, prejudice toward Aboriginal people will be partitioned into old-fashioned and modern components (Anderson, 2010; McConahay, 1986). The former emphasizes characterological defects (e.g., "Aboriginal people smell and are lazy") and may be openly hostile; in contrast, the latter is more subtle and focuses on beliefs such as "Aboriginal people have all the rights they need," and "Discrimination against Aboriginal people is a thing of the past." Modern prejudice may be founded upon moral concerns that minority groups are making illegitimate demands for changes to the status quo (Morrison \& Morrison, 2002); that minority groups receive unfair advantages (Durrheim \& Dixon, 2004); and current generations are no longer culpable for past injustices.

Researchers also acknowledge that prejudice can often be generalized across targets; thus, an individual who displays prejudiced attitudes toward one outgroup (e.g., Aboriginal peoples) is likely to display similarly prejudiced attitudes toward other outgroups (e.g., sexual minorities) (Akrami, Ekehammer, \& Bergh, 2011; Allport, 1954; Asbrock, Sibley, \& Duckitt, 2010). Subsequent research has consistently found prejudice towards a variety of targets to be significantly correlated, with factor analyses typically yielding a generalized prejudice factor explaining $50 \%$ to $60 \%$ of the variance (Akrami et al., 2011). Among demographic factors predicting generalized prejudice, past studies have shown greater levels of prejudice in individuals that are older, male, reside in nonurban areas, have lower levels of education, and are more religious (Eitle \& Steffens, 2009; Keatings, Innes, Laliberte, \& Howe, 2012; Morrison \& Morrison, 2011; Morrison et al., 2008; Pedersen \& Walker, 1998; Pincus, 1996). Also, prejudicial attitudes are consistently found to correlate positively with conservative sociopolitical values such as right-wing authoritarianism (RWA), social dominance orientation (SDO), and conventionalism (Altemeyer, 1994; Bierly, 1985; Mirisola, Sibley, Boca, \& Duckitt, 2007; Pratto, Sidanius, Stallworth, \& Malle 1994; Sibley, Robertson, \& Wilson, 2006; Weigel \& Howes, 1985). Finally, research indicates that contact with members of stigmatized groups and the dispositional variable of empathy correlate negatively with prejudiced attitudes (e.g., Bäckström \& Björklund, 2007; Pettigrew, Christ, Wagner, \& Stellmacher, 2007).

Based on the model of generalised prejudice articulated above, it is predicted that individuals evidencing greater negativity toward Aboriginal persons also will evidence more negativity toward other marginalized groups; namely, gay men and overweight persons ( $H 1)$. Indices of conservative sociopolitical values (specifically, rightwing authoritarianism and social dominance orientation) will correlate positively with negative attitudes toward Aboriginal persons ( $H 2 \& H 3$ ). As blatant negativity toward marginalised groups, characteristic of old-fashioned prejudice, is becoming less acceptable (e.g., Anderson, 2010; Cuddy, Norton, \& Fiske, 2005; Kinder, 1986; Morrison \& Morrison, 2002; Pedersen \& Walker, 1997), it is predicted that respondents will evidence greater endorsement of modern prejudice than old-fashioned prejudice toward Aboriginal persons $(\mathrm{H} 4)$.

The following hypotheses pertain to the second sample which completed the modern measure of prejudice toward Aboriginal persons. In accordance with studies suggesting that religiosity correlates positively with prejudice (e.g., Johnson, Rowatt, \& LaBouff, 2012), it is hypothesised that individuals reporting greater levels of religiousness will evidence greater modern prejudice toward Aboriginal persons (H5). Finally, contact and em- 
pathy are inversely associated with modern sexism, modern racism, and generalised prejudice (Bäckström \& Björklund, 2007; Pettigrew et al., 2007); thus, it is predicted that participants evidencing greater levels of empathy and more positive contact with Aboriginal persons will report lower levels of modern prejudice (H6 \& H7).

\section{Method}

\subsection{Participants}

Sample 1 consisted of 280 undergraduate students. Most respondents were Caucasian (84.2\%, $n=213)$, female (71.6\%, $n=199)$, ranged in age from 17 to $35(M=19.68$; $S D=2.85)$, and self -identified as politically liberal $(47.7 \%, n=124)$. For Sample 2, 163 individuals (70.9\% female) provided usable data. Their mean age was 28.89 $(S D=10.51)$ and the majority identified as Caucasian (93.9\%). In terms of their political affiliation, $27 \%$ selfidentified as conservative, $39 \%$ as liberal, and $34 \%$ as neither liberal nor conservative.

\subsection{Measures}

The following scales were distributed to Sample 1.

Anti-Fat Attitudes Scale (AFAS). Morrison and O’Connor's (1999) 5-item AFAS provides a measure of oldfashioned (i.e., blatant) prejudice toward overweight individuals. The AFAS uses a 5-point Likert-type scale (1 = strongly disagree; 5 = strongly agree). Total scores can range from 5 to 25 (midpoint 15), with higher scores suggesting greater negativity toward persons that are fat. Previous studies have found the AFAS to be a psychometrically robust measure of anti-fat attitudes (e.g., Morrison \& O'Connor, 1999); in the present study, however, Cronbach's alpha for the AFAS was poor: females $.47(95 \% \mathrm{CI}=.34-.58)$ and males .37 (95\% CI $=.12-.57)$.

Modern Homonegativity Scale (MHS). Morrison and Morrison's (2002) 12-item Modern Homonegativity Scale assesses contemporary negative attitudes toward gay men and lesbian women. Both subscales use a 5-point Likert-type scale ranging from 1 (strongly disagree) to 5 (strongly agree). Total scores on the MHS can range from 12 to 60, with a midpoint of 36. Higher scores denote greater homonegativity. Myriad studies have examined the psychometric properties of the MHS (see Rye \& Meaney, 2010). Two parallel versions of the MHS were distributed to participants in the present study: one focusing on gay men (MHS-G) and the other on lesbian women (MHS-L). As no statistically significant differences were observed between the two groups, their data were combined. In the present study, Cronbach's alphas for the MHS were: females .78 (95\% CI = .73 - .82) and males $.86(95 \% \mathrm{CI}=.81-.90)$.

M-PATAS. Morrison et al.'s (2008) 14-item Modern Prejudiced Attitudes toward Aboriginals Scale (MPATAS) was used in the present study to measure modern (i.e., covert and subtle) prejudice towards Aboriginal peoples. In the current study, a 5-point Likert-type scale, ranging from 1 (strongly disagree) to 5 (strongly agree), was employed. Thus, the M-PATAS had a minimum score of 14 and a maximum of 70 (midpoint of 42), with higher scores reflecting more prejudiced attitudes. Morrison and Associates (2008) provide evidence in support of the measure's scale score reliability, factorial, and convergent validity. In the present study, Cronbach's alphas were: females $.87(95 \% \mathrm{CI}=.84-.89)$ and males $.88(95 \% \mathrm{CI}=.84-.92)$.

O-PATAS. Morrison et al.'s (2008) 11-item Old-fashioned Prejudiced Attitudes toward Aboriginals Scale (O-PATAS) measures blatantly pejorative beliefs about Aboriginal peoples. In the current study, a 5-point Likert-type scale, ranging from 1 (strongly disagree) to 5 (strongly agree), was used. Total scores can range from 11 to 55 (midpoint 33), with higher scores reflecting more prejudiced attitudes. Previous research (Morrison et al., 2008) attests to the measure's scale score reliability, convergent, and factorial validity. In the present study, Cronbach's alphas were: males $.88(95 \% \mathrm{CI}=.84-.92)$ and females $.81(95 \% \mathrm{CI}=.77-.85)$.

Political Orientation. Participants were asked to indicate their political orientation: Very liberal, liberal, somewhat liberal, somewhat conservative, conservative, or very conservative. Participants also were given the option of "prefer not to answer". Scores ranged from 1 to 6, with higher scores reflecting greater political conservatism. Single-item measures of political conservatism have been found to be reliable and valid (Gerbner, Gross, Morgan, \& Signorielli, 1994).

Right Wing Authoritarianism Scale (RWA). This construct was assessed with Altemeyer's (2006) 22-item measure of RWA. This instrument employs a 9-point semantic differential scale ranging from -4 (very strongly disagree) to +4 (very strongly agree), with a midpoint of 0 . Scoring of the RWA Scale involves assigning a value of 9 to every regularly scored scale item with a response of +4 , a value of 8 for a response of +3 , and so on, 
culminating with a value of 1 for a response of -4 . To control for acquiescence, scoring of the RWA Scale is reversed on 10 items. In scoring this scale, the first two items are omitted, as they serve to familiarize participants with the measure's somewhat unconventional response continuum. The RWA Scale has a minimum score of 20, a maximum score of 180, and a midpoint of 100, with higher scores reflecting greater adherence to RWA. Altemeyer (2006) has demonstrated the psychometric soundness of various iterations of the RWA. In the present study, Cronbach's alphas for the RWA Scale were: .88 (95\% CI $=.85-.90)$ for females and .90 (95\% CI = .86 - .93) for males.

Social Dominance Orientation Scale (SDO). The 8-item version of the SDO scale was used in this study (Pratto et al., 1994). The amended scale employed a 5-point Likert-type scale ranging from 1 (strongly disagree) to 5 (strongly agree). Total scores can range from 8 to 40 (midpoint $=24$ ), with higher values reflecting greater adherence to SDO. In the present study, Cronbach's alpha coefficients were: .87 (95\% CI $=.83-.89$ ) for females and $.82(95 \% \mathrm{CI}=.75-.87)$ for males.

For Sample 2, the following scales were completed.

Duke University Religion Index (DUREL). Koenig and Bussing's (2010) 5-item measure assesses various facets of religiosity including organizational religious activity and intrinsic (or subjective) religiousness. The DUREL uses a 6-point Likert-type scale $(1=$ never; 6 = more than once $a$ day $)$ for two questions and a 5-point Likert-type scale for three questions $(1=$ definitely not true; $5=$ definitely true of me). Total scores can range from 5 to 27 (midpoint 15.5), with higher scores denoting greater levels of religiosity. In the current study, standardized scale score reliability coefficients were $.90(95 \% \mathrm{CI}=.87-.93)$ for females, and $.88(95 \% \mathrm{CI}=.81$ - .92) for males.

Empathy. Davis' (1980) 9-item measure of empathic concern was used ( 1 = definitely not true of me; 5 = definitely true of me). Total scores can range from 9 to 45 with higher scores representing greater empathy. In the current study, Cronbach's alpha coefficients were: .77 (95\% CI = .66 - .86) and .78 (95\% CI = .71 - .84) for males and females, respectively.

M-PATAS. A description of this scale is provided with Sample 1. However, for the current group, a 7-point response format was used ( 1 = strongly disagree; 7 = strongly agree). Cronbach's alpha coefficients were: .93 (95\% $\mathrm{CI}=.92-.95)$ for females, and $.95(95 \% \mathrm{CI}=.92-.97)$ for males.

Positive Previous Contact. Plant and Devine's (2003) 3-item measure of positive previous experience with Black people was used, with the target changed to Aboriginal persons. The scale uses a 7-point response format ( 1 = strongly disagree; 7 = strongly agree), with total scores ranging from 3 to 21 (midpoint 12). Higher scores reflect more positive previous experience with the minority group in question. In the current study, Cronbach's alpha coefficients were: $.58(95 \% \mathrm{CI}=.32$ - .76) for males and .69 $(95 \% \mathrm{CI}=.58$ - .78$)$ for females.

\subsection{Procedure}

Sample 1 participants were recruited using diverse strategies such as poster advertisements, chain-referral sampling (i.e., word-of-mouth), and the Undergraduate Psychology Participant Pool. Participants completed the pen and paper version of the survey while attending one of a series of group data collection sessions held in a classroom at the researchers' institution. Prior to commencing the survey, the researcher responsible for collecting the data gave participants a brief overview of the study; instructions for completion of the survey; and informed participants of their right to withdraw without penalty. Assurances of confidentiality and anonymity also were issued at that time. Those completing the online survey did so at a location of their choosing. A cover sheet detailed all of the points raised in person by the researcher during the group sessions. For both the online and group participants, the survey took approximately 20 minutes to complete.

Sample 2 was recruited using chain-referral sampling, with all data collected via online surveys. The cover sheet stipulated clearly that participation was voluntary and could be terminated at any time. Any respondent that commenced with the survey was regarded as agreeing with the terms and conditions outlined on the cover sheet.

\section{Results}

For Sample 1, means and standard deviations for all scales, stratified by gender, are provided in Table 1. Only one statistically significant difference between male and female respondents was observed: male participants displayed slightly greater anti-fat prejudice; however, the effect size for this difference was modest. 
Table 1. Means and standard deviations on key measures (Sample 1).

\begin{tabular}{ccc}
\hline Measure & Mean & Standard Deviation \\
\hline O-PATAS & $30.84(\mathrm{~F}) 29.21(\mathrm{M})$ & $6.89(\mathrm{~F}) 8.12(\mathrm{M})$ \\
M-PATAS & $41.75(\mathrm{~F}) 43.10(\mathrm{M})$ & $9.44(\mathrm{~F}) 9.71(\mathrm{M})$ \\
MHS & $32.53(\mathrm{~F}) 34.20(\mathrm{M})$ & $6.74(\mathrm{~F}) 8.49(\mathrm{M})$ \\
AFAS & $13.55^{*}(\mathrm{~F}) 14.55(\mathrm{M})$ & $3.09(\mathrm{~F}) 2.99(\mathrm{M})$ \\
SDO & $18.24(\mathrm{~F}) 18.43(\mathrm{M})$ & $6.05(\mathrm{~F}) 5.70(\mathrm{M})$ \\
RWA & $73.47(\mathrm{~F}) 70.92(\mathrm{M})$ & $22.36(\mathrm{~F}) 26.18(\mathrm{M})$ \\
\hline
\end{tabular}

Note: $\mathrm{F}=$ female; $\mathrm{M}=$ male; ${ }^{*} t(270)=-2.40, p<.05, d=-.33$.

In accordance with the first hypothesis, respondents evidencing prejudice toward Aboriginal men and women also evidenced prejudice toward gay men and overweight persons suggesting that negativity toward marginalized groups is a generalized phenomenon; one that transcends sexuality, aesthetic value, and skin colour. Also, as predicted, prejudice toward Aboriginal persons correlated positively with endorsement of conservative sociopolitical ideologies; namely, RWA and SDO (see Table 2). Statistically significant correlations between selfreported political conservatism and scores on the OPATAS and MPATAS emerged for female, but not male, participants.

It was predicted that respondents would be more likely to endorse modern rather than old-fashioned prejudice toward Aboriginal persons. As the OPATAS and MPATAS have different numbers of scale items, both instruments were standardized (i.e., total score/total number of items). Paired samples t-tests revealed that female participants' endorsement of modern prejudice toward Aboriginal persons was significantly higher $(M=3.04$, SD $=.64)$ than their endorsement of old-fashioned prejudice $(M=2.84, S D=.60), t(180)=4.60, p<.001, d=.32$. A similar difference emerged for male respondents: endorsement of modern prejudice $(M=3.08, S D=.70)$ was greater than endorsement of old-fashioned prejudice $(M=2.66, S D=.75), t(74)=5.08, p<.001, d=.58$.

To contextualise rates of endorsement of modern and old-fashioned prejudice, as measured by the OPATAS and MPATAS, proportions of agreement are listed in Table 3 and Table 4.

With the second sample, independent samples t-tests revealed that male and female respondents did not differ in their level of modern prejudice toward Aboriginal persons (males, $M=62.52, S D=19.90$; females, $M=60.29$, $S D$ $=18.06 ; t(156)=.69$ ); their level of empathy (males, $M=33.15, S D=5.19$; females, $M=34.19, S D=4.69 ; t(156)$ $=-1.22$ ); or self-reported positive contact experience with Aboriginal people (males, $M=9.96, S D=2.09$; females, $M=9.77, S D=2.47 ; t(156)=.45)$. However, females did evidence greater levels of religiosity $(M=11.58$, $S D=5.77)$ than their male counterparts $(M=8.52, S D=4.66), t(102.862)=-3.488, p<.001, d=.58$.

As predicted, male and female participants' levels of empathy were inversely associated with their modern prejudice toward Aboriginal people ( $r s=-.51$ and $-.38, p<.001$, respectively). Previous positive contact also correlated negatively with endorsement of modern prejudice for both male $(r=-.31, p<.05)$ and female $(r=-.38$, $p<.001)$ respondents. However, contrary to our prediction, religiosity did not correlate significantly with modern prejudice: males, $r=-.10$ and females, $r=.12$.

\section{Discussion}

Overall, the results of the present study suggest that endorsement of prejudicial attitudes toward Aboriginal people in Canada is alarmingly high. Over two data collection sessions, separated by 18 months, using both university and non-university respondents, large proportions of men and women agree that Aboriginal people exploit their cultural traditions to "secure special rights," "should stop complaining about the way they are treated," and make "excessive demands" to the Canadian government. Although participants were more inclined to endorse modern prejudice, surprisingly high levels of old-fashioned negativity emerged, with sizeable proportions agreeing that Aboriginal people “sound drunk,” “cannot take care of their children,” are “on welfare,” and abuse drugs. Also, of note are the appreciably higher levels of modern prejudice observed with Sample 2, which consisted primarily of non-university students. Such results suggest that members of the general community appear to have little compunction in endorsing negative belief statements about Aboriginal persons. 
Table 2. Correlations among key measures, stratified by gender (Sample 1).

\begin{tabular}{|c|c|c|c|c|c|c|c|}
\hline Measure & 1 & 2 & 3 & 4 & 5 & 6 & 7 \\
\hline 1) OPATAS & & .56 & .42 & .43 & .60 & .37 & .31 \\
\hline 2) MPATAS & .50 & & .34 & .24 & .57 & .23 & .29 \\
\hline 3) MHS & .59 & .41 & & .27 & .38 & .65 & .26 \\
\hline 4) AFAS & .38 & .31 & .37 & & .21 & .24 & .03 \\
\hline 5) $\mathrm{SDO}$ & .57 & .27 & .46 & .23 & & .37 & .23 \\
\hline 6) RWA & .36 & .05 & .53 & .16 & .29 & & .31 \\
\hline 7) PC & .15 & .11 & .39 & -.10 & .30 & .39 & \\
\hline
\end{tabular}

Note: Female $r$ vales are above the diagonal; PC = Political Conservatism; all $r$ values $|23| p<.05$; $r$ values in bold possess "practical significance”; due to poor scale score reliability, all correlations for the AFAS are underestimates.

Table 3. Endorsement rates for items assessing old-fashioned prejudice toward aboriginals.

\begin{tabular}{lcc}
\hline \multicolumn{1}{c}{ OPATAS } & Male Respondents & Female Respondents \\
\hline Aboriginal people have no sense of time. & $16.7 \%$ & $23.7 \%$ \\
Most Aboriginal people cannot take care of their children. & $28.2 \%$ & $\mathbf{3 5 . 5 \%}$ \\
Most Aboriginal people are on welfare. & $28.2 \%$ & $27.8 \%$ \\
Most Aboriginal people sound drunk. & $\mathbf{3 3 . 3 \%}$ & $\mathbf{4 7 \%}$ \\
Poverty on reserves is a direct result of Aboriginal people abusing drugs. & $19.5 \%$ & $23.5 \%$ \\
Most Aboriginal people need classes on how to be better parents. & $19.5 \%$ & $24.7 \%$ \\
Diseases that affect Aboriginal people are simply due to the lifestyle they lead. & $20.5 \%$ & $23.5 \%$ \\
Few Aboriginal people seem to take much pride in their physical appearance. & $18 \%$ & $22 \%$ \\
High standards of hygiene are not valued in Aboriginal culture. & $16.6 \%$ & $19.2 \%$ \\
Aboriginal people have way too many children. & $16.6 \%$ & $17.6 \%$ \\
Drug abuse is a key problem among Aboriginal people. & $\mathbf{6 3 . 7 \%}$ & $\mathbf{6 2 . 6 \%}$ \\
\hline
\end{tabular}

Note: Endorsement rates $>30 \%$ are in bold.

An exploration of the thematic linkages among the most heavily supported items from the M-PATAS and O-PATAS point toward the existence of two related and particularly widespread beliefs with respect to modern and old-fashioned prejudice toward Aboriginal peoples. The first of these is an apparent conflation of affirmative action policies with racial privileging. Consistent with past literature (Dovidio, Mann, \& Gaertner, 1989; Fine, 1992) which has found Caucasian Americans to be considerably less supportive of preferential hiring practices than their African American counterparts, and to oppose redistributive governmental programs in general (Rabinowitz, Sears, Sidanius, \& Krosnick, 2009), the results of the present study found an overwhelming majority of participants agree that "Aboriginal people should not have reserved placements in universities unless they are qualified". A large proportion also agreed with the statement "Special places in academic programs should not be set aside for Aboriginal students." Unfortunately, such a pattern of findings highlights a perennial difficulty in reducing prejudiced attitudes more generally: even if the notion of equality may find strong support in principle, efforts toward its substantive realization may be hindered by reluctance on the part of the majority to recognize the need for or efficacy of affirmative action policies aimed at reducing social inequalities.

The results of this study also illuminate the need to correct misinformation about Aboriginal entitlements. Specifically, Aboriginal peoples are neither excluded from paying taxes nor are privy to a range of economic benefits withheld from non-Aboriginal Canadians. In parallel with the results of Keatings et al. (2012), who found two-thirds of their sample $(N=1750)$ of non-Aboriginal residents of Saskatchewan agreed with the statement 
Table 4. Endorsement rates for items assessing modern prejudice toward aboriginals.

\begin{tabular}{|c|c|c|c|c|}
\hline \multirow{2}{*}{ MPATAS } & \multicolumn{2}{|c|}{ Male Respondents } & \multicolumn{2}{|c|}{ Female Respondents } \\
\hline & S1 & S2 & S1 & S2 \\
\hline $\begin{array}{l}\text { Aboriginal people should stop complaining about the way they are treated, } \\
\text { and simply get on with their lives. }\end{array}$ & $24.4 \%$ & $33.9 \%$ & $29.4 \%$ & $26.8 \%$ \\
\hline $\begin{array}{l}\text { Canada needs to stop apologizing for events that happened } \\
\text { to Aboriginal people many years ago. }\end{array}$ & $35.9 \%$ & $52.2 \%$ & $38.5 \%$ & $36.6 \%$ \\
\hline $\begin{array}{l}\text { Non-Aboriginal people need to become more sensitive to the needs of Aboriginal } \\
\text { people. }\end{array}$ & $25.6 \%^{*}$ & $30.4 \%{ }^{*}$ & $23.6 \%^{*}$ & $32.2 \%{ }^{*}$ \\
\hline $\begin{array}{l}\text { Aboriginal people seem to use their cultural traditions to secure special } \\
\text { rights denied to non-Aboriginal Canadians. }\end{array}$ & $47.4 \%$ & $45.7 \%$ & $57 \%$ & $40.2 \%$ \\
\hline Aboriginal people should pay taxes like everyone else. & $57.5 \%$ & $54.4 \%$ & $54.5 \%$ & $63.4 \%$ \\
\hline $\begin{array}{l}\text { The government should support programmes designed to place Aboriginal people in } \\
\text { positions of power. }\end{array}$ & $33.8 \%{ }^{*}$ & $19.5 \%{ }^{*}$ & $23 \%{ }^{*}$ & $15.2 \%^{*}$ \\
\hline It is now unnecessary to honour treaties established with Aboriginal people. & $14.1 \%$ & $17.1 \%$ & $13 \%$ & $12.6 \%$ \\
\hline Special places in academic programmes should not be set aside for Aboriginal students. & $39.8 \%$ & $39.1 \%$ & $51.9 \%$ & $32.2 \%$ \\
\hline Aboriginal people still need to protest for equal rights. & $38.4 \%{ }^{*}$ & $19.5 \%{ }^{*}$ & $31.2 \%{ }^{*}$ & $29.5 \%{ }^{*}$ \\
\hline $\begin{array}{l}\text { Aboriginal people should simply get over past generations' experiences } \\
\text { at residential schools. }\end{array}$ & $33.3 \%$ & $28.3 \%$ & $19.8 \%$ & $16.1 \%$ \\
\hline $\begin{array}{l}\text { Many of the requests made by Aboriginal people to the Canadian government } \\
\text { are excessive. }\end{array}$ & $42.3 \%$ & $39.1 \%$ & $41.2 \%$ & $29.5 \%$ \\
\hline Aboriginal people should be satisfied with what the government has given them. & $37.1 \%$ & $26.1 \%$ & $48.6 \%$ & $29.5 \%$ \\
\hline $\begin{array}{l}\text { Aboriginal people should not have reserved placements in universities unless they } \\
\text { are qualified. }\end{array}$ & $65.4 \%$ & $60.9 \%$ & $71.6 \%$ & $61.6 \%$ \\
\hline Government agencies should make every effort to meet the needs of Aboriginal people & $29.9 \%^{*}$ & $17.4 \%{ }^{*}$ & $29.9 \%{ }^{*}$ & $15.2 \%{ }^{*}$ \\
\hline
\end{tabular}

Note: "Proportion that "strongly disagree/disagree”; items in bold denote endorsement rates > 30\%; S1 = Sample 1, S2 = Sample 2.

“Aboriginal people do not pay enough taxes in Saskatchewan,” a majority of participants in the present study concurred that "Aboriginals should pay taxes just like everyone else." Such beliefs appear to be a result of misinformation regarding the (exceptionally limited) range of specific tax exemptions afforded to qualifying status Indians under section 87 of the Indian Act.

As predicted, prejudice toward Aboriginal people was associated with endorsement of right-wing authoritarianism and social dominance orientation, with the latter emerging as a particularly robust correlate of prejudice toward Aboriginal persons. Rather fittingly, the narrative content of many of the most strongly endorsed items from the M-PATAS and O-PATAS are consistent with the hierarchy-enhancing legitimizing myths (HE-LMs) described by Pratto, Sidanius, and Levin (2006) as playing a critical role in intergroup prejudice within the framework of social dominance theory. HE-LMs are described as being premised upon "internal attributions for poverty", and are "used to argue that inequality is fair, legitimate, natural, or moral” (Pratto et al., 2006: pp. 275276). The results of the present study reveal widespread acceptance of precisely such attributions of internal causality. Furthermore, HE-LMs contain strong opposition to redistributive policies aimed at attenuating social hierarchies and, as mentioned previously, the results of our study clearly illustrate a pronounced opposition to such policies.

In accordance with the view that prejudice is a generalised phenomenon, those endorsing negative belief statements about Aboriginal persons also evidenced negativity toward other stigmatized groups (namely, gay and lesbian persons and overweight individuals). The statistical significance of the correlations between scores on the Anti-Fat Attitudes Scale (AFAS) and the O-PATAS and M-PATAS is particularly noteworthy as the AFAS had 
low scale score reliability coefficients, which suggest greater random measurement error. Correcting for the attenuation in $r$ values due to poor Cronbach's alpha coefficients increases the magnitude of these correlations appreciably (e.g., $r=.38$ [males: AFAS/O-PATAS] becomes $r=.67$ when a correction formula is applied).

Both positive contact with Aboriginal persons and the dispositional variable of empathy were inversely associated with modern prejudice. Such associations underscore the need for researchers to explore strategies designed to increase empathy and promote positive contact between non-Aboriginal and Aboriginal persons.

Contrary to our predictions, male participants did not evidence greater levels of prejudice. This result is unorthodox (i.e., findings examining prejudice toward Aboriginal Australians, for example, consistently find that males evidence greater levels of prejudice than do females — see Feather \& McKee, 2008); thus, additional studies using the O-PATAS and M-PATAS are needed to determine whether the absence of gender differences identified in the current study is idiosyncratic or robust. As well, no association was observed between religiosity and modern prejudice toward Aboriginal persons. This finding may be attributable to a measure of religiousness that, while more comprehensive that single item indicators, omitted key dimensions such as religious particularism (i.e., the belief that there is one true religion), self-identification as a religious person, and denominational membership (Scheepers, Gijsberts, \& Hello, 2002). Scheepers et al. note that all of these elements bear differential associations with prejudice.

Finally, two limitations to the current study should be noted. First, in both the university and community samples, there was a pronounced imbalance between male and female participants. Efforts should be made to recruit larger numbers of men. Second, while endorsement rates were high for select items, the overall means were slightly above scale midpoints. The inclusion of a "neither disagree nor agree" response option may have contributed to this phenomenon. Subsequent use of the O-PATAS and M-PATAS may benefit from omitting this option and requiring participants to evidence either a prejudicial (agree) or non-prejudicial (disagree) stance.

\section{Conclusion}

In conclusion, the results of this study suggest that levels of prejudice directed toward Aboriginal persons in Canada are alarmingly high, especially among the community participants we recruited. Educational strategies designed to crystalize the abuses that Aboriginal persons have suffered in the past and continue to suffer today; highlight the neglect this group has received from the Canadian government; and shatter misinformation about Aboriginal entitlements may serve to engender empathy toward members of this group and, in so doing, attenuate non-Aboriginals' prejudice.

\section{References}

Akrami, N., Ekehammer, B., \& Bergh, R. (2011). Generalized Prejudice: Common and Specific Components. Psychological Science, 22, 57-59. http://dx.doi.org/10.1177/0956797610390384

Allport, G. W. (1954). The Nature of Prejudice. Cambridge, MA: Perseus Books.

Altemeyer, B. (1994). Reducing Prejudice in Right-Wing Authoritarians. In M. P. Zanna, \& J. M. Olson (Eds.), The Psychology of Prejudice (pp. 131-148). Mahwah, NJ: Erlbaum.

Altemeyer, B. (2006). The Authoritarians. www.theauthoritarians.com

Anderson, K. (2010). Benign Bigotry: The Psychology of Subtle Prejudice. Cambridge: Cambridge University Press.

Asbrock, F., Sibley, C., \& Duckitt, J. (2010). Right-Wing Authoritarianism and Social Dominance Orientation and the Dimensions of Generalized Prejudice: A Longitudinal Test. European Journal of Personality, 24, 324-340. http://dx.doi.org/10.1002/per.746

Bäckström, M., \& Björklund, F. (2007). Structural Modeling of Generalized Prejudice the Role of Social Dominance, Authoritarianism, and Empathy. Journal of Individual Differences, 28, 10-17. http://dx.doi.org/10.1027/1614-0001.28.1.10

Bartlett, R. (1980). Citizens Minus: Indians and the Right to Vote. Saskatchewan Law Review, 44, 163-194.

Bierly, M. (1985). Prejudice toward Contemporary Outgroups as a Generalized Attitude. Journal of Applied Social Psychology, 15, 189-199. http://dx.doi.org/10.1111/j.1559-1816.1985.tb02344.X

Brave Heart, M. Y. H., \& DeBruyn, L. (1998). The American Indian Holocaust: Healing Historical Unresolved Grief. American Indian and Alaska Native Mental Health Research, 8, 60-82. http://dx.doi.org/10.5820/aian.0802.1998.60

Claxton-Oldfield, S., \& Keefe, S. M. (1999). Assessing Stereotypes about the Innu of Davis Inlet, Labrador. Canadian Journal of Behavioural Science, 31, 86-91. http://dx.doi.org/10.1037/h0087076 
Cuddy, A., Norton, M., \& Fiske, S. (2005). This Old Stereotype: The Pervasiveness and Persistence of the Elderly Stereotype. Journal of Social Issues, 61, 265-283. http://dx.doi.org/10.1111/j.1540-4560.2005.00405.x

Davis, M. H. (1980). A Multidimensional Approach to Individual Differences in Empathy. Catalog of Selected Documents in Psychology, 10, 1-19.

Dovidio, J., Mann, J., \& Gaertner, S. (1989). Resistance to Affirmative Action: The Implications of Aversive Racism. In A. Blanchard \& F. Crosby (Eds.), Affirmative Action in Perspective (pp. 83-102). New York: Springer-Verlag. http://dx.doi.org/10.1007/978-1-4613-9639-0_7

Durrheim, K., \& Dixon, J. (2004). Attitudes in the Fiber of Everyday Life: The Discourse of Racial Evaluation and the Lived Experience of Desegregation. American Psychologist, 59, 626-636. http://dx.doi.org/10.1037/0003-066X.59.7.626

Eitle, T. M., \& Steffens, M. (2009). Religious Affiliation and Beliefs about Racial Inequality: White College Students’ Attitudes about Black-White and Native American-White Inequality. The Social Science Journal, 46, 506-520. http://dx.doi.org/10.1016/j.soscij.2009.02.004

Feather, N. T., \& McKee, I. R. (2008). Values and Prejudice: Predictors of Attitudes toward Australian Aborigines. Australian Journal of Psychology, 60, 80-90. http://dx.doi.org/10.1080/00049530701449513

Fine, T. (1992). The Impact of Issue Framing on Public Opinion toward Affirmative Action Programs. The Social Science Journal, 29, 323-334. http://dx.doi.org/10.1016/0362-3319(92)90025-D

Gerbner, G., Gross, L., Morgan, M., \& Signorielli, N. (1994). Political Correlates of Television Viewing. Public Opinion Quarterly, 48, 283-300. http://dx.doi.org/10.1093/poq/48.1B.283

Haddock, G., Zanna, M., \& Esses, V. (1994). The (Limited) Role of Trait-laden Stereotypes in Predicting Attitudes toward Native Peoples. British Journal of Social Psychology, 33, 83-106. http://dx.doi.org/10.1111/j.2044-8309.1994.tb01012.x

Johnson, M. K., Rowatt, W. C., \& LaBouff, J. P. (2012). Religiosity and Prejudice Revisited: In-Group Favoritism, OutGroup Derogation, or Both? Psychology of Religion and Spirituality, 4, 154-168. http://dx.doi.org/10.1037/a0025107

Keatings, T., Innes, R., Laliberte, R., \& Howe, E. (2012). Taking the Pulse of Saskatchewan 2012: Aboriginal Issues in Saskatchewan. Saskatoon: Social Sciences Research Laboratories, University of Saskatchewan.

Kinder, D. R. (1986). The Continuing American Dilemma: White Resistance to Racial Change 40 Years after Myrdal. Journal of Social Issues, 42, 151-171. http://dx.doi.org/10.1111/j.1540-4560.1986.tb00230.x

Kirmayer, L., Tait, C., \& Simpson, C. (2009). The Mental Health of Aboriginal Peoples in Canada: Transformations of Identity and Community. In L. Kirmayer, \& G. Valaskakis (Ed.), Healing Traditions: The Mental Health of Aboriginal Peoples in Canada (pp. 1-35). Vancouver: UBC Press.

Koenig, H. G., \& Bussing, A. (2010). The Duke University Religion Index (DUREL): A Five-Item Measure for Use in Epidemiological Studies. Religions, 1, 78-85. http://dx.doi.org/10.3390/rel1010078

Maaka, R., \& Andersen, C. (2006). The Indigenous Experience: Global Perspectives. Toronto: Canadian Scholars’ Press.

McConahay, J. B. (1986). Modern Racism, Ambivalence, and the Modern Racism Scale. In J. F. Dovidio \& S. L. Gaertner (Eds.), Prejudice, Discrimination, and Racism (pp. 91-125). San Diego, CA: Academic Press.

Mirisola, A., Sibley, C., Boca, S., \& Duckitt, J. (2007). On the Ideological Consistency between Right-Wing Authoritarianism and Social Dominance Orientation. Personality and Individual Differences, 43, 1851-1862. http://dx.doi.org/10.1016/i.paid.2007.06.006

Morrison, M. A., \& Morrison, T. G. (2002). Development and Validation of a Scale Measuring Modern Prejudice toward Gay Men and Lesbian Women. Journal of Homosexuality, 43, 15-37. http://dx.doi.org/10.1300/J082v43n02_02

Morrison, M. A., \& Morrison, T. G. (2011). Sexual Orientation Bias toward Gay Men and Lesbian Women: Modern Homonegative Attitudes and Their Associations with Discriminatory Behavioural Intentions. Journal of Applied Social Psychology, 41, 2573-2599. http://dx.doi.org/10.1111/j.1559-1816.2011.00838.x

Morrison, M. A., Morrison, T. G., Harriman, R., \& Jewell, L. (2008). Old-Fashioned and Modern Prejudice toward Aboriginals in Canada. In M. A. Morrison, \& T. G. Morrison (Eds.), The Psychology of Modern Prejudice (pp. 277-305). New York: Nova Science.

Morrison, T. G., \& O’Connor, W. E. (1999). Psychometric Properties of a Scale Measuring Negative Attitudes toward Overweight Individuals. The Journal of Social Psychology, 139, 436-445. http://dx.doi.org/10.1080/00224549909598403

Moss, W., \& Gardner-O’Toole, E. (1991). Law and Government Division. Aboriginal Peoples: History of Discriminatory Laws (BP-175E). http://publications.gc.ca/Collection-R/LoPBdP/BP/bp175-e.htm

Pedersen, A., \& Walker, I. (1998). Prejudice against Australian Aborigines: Old-Fashioned and Modern Forms. European Journal of Social Psychology, 27, 561-587.

http://dx.doi.org/10.1002/(SICI)1099-0992(199709/10)27:5<561::AID-EJSP833>3.0.CO;2-3 
Pettigrew, T. F., Christ, O., Wagner, U., \& Stellmacher, J. (2007). Direct and Indirect Intergroup Contact Effects on Prejudice: A Normative Interpretation. International Journal of Intercultural Relations, 31, 411-425. http://dx.doi.org/10.1016/j.ijintrel.2006.11.003

Pincus, F. L. (1996). Discrimination Comes in Many Forms: Individual, Institutional, and Structural. American Behavioral Scientist, 40, 186-194. http://dx.doi.org/10.1177/0002764296040002009

Plant, E. A., \& Devine, P. G. (2003). The Antecedents and Implications of Interracial Anxiety. Personality and Social Psychology Bulletin, 29, 790-801. http://dx.doi.org/10.1177/0146167203029006011

Pratto, F., Sidanius, J., \& Levin, S. (2006). Social Dominance Theory and the Dynamics of Intergroup Relations: Taking Stock and Looking Forward. European Review of Social Psychology, 17, 271-320. http://dx.doi.org/10.1080/10463280601055772

Pratto, F., Sidanius, J., Stallworth, L., \& Malle, B. (1994). Social Dominance Orientation: A Personality Variable Predicting Social and Political Attitudes. Journal of Personality and Social Psychology, 67, 741-763. http://dx.doi.org/10.1037/0022-3514.67.4.741

Rabinowitz, J., Sears, D., Sidanius, J., \& Krosnick, J. (2009). Why Do White Americans Oppose Race-Targeted Policies? Clarifying the Impact of Symbolic Racism. Political Psychology, 30, 805-828. http://dx.doi.org/10.1111/j.1467-9221.2009.00726.x

Rye, B. J., \& Meaney, G. J. (2010). Measuring Homonegativity: A Psychometric Analysis. Canadian Journal of Behavioural Science, 42, 158-167. http://dx.doi.org/10.1037/a0018237

Scheepers, P., Gijsberts, M., \& Hello, E. (2002). Religiosity and Prejudice against Ethnic Minorities in Europe: Cross-National Tests on a Controversial Relationship. Review of Religious Research, 43, 242-265. http://dx.doi.org/10.2307/3512331

Sibley, C., Robertson, A., \& Wilson, M. (2006). Social Dominance Orientation and Right-Wing Authoritarianism: Additive and Interactive Effects. Political Psychology, 27, 755-768.

Statistics Canada (2010). Aboriginal Statistics at a Glance. Ottawa: Statistics Canada Catalogue No. 89-645-X.

Waldram, J. B. (2004). Revenge of the Windigo: The Construction of the Mind and Mental Health of North American Aboriginal Peoples. Toronto: University of Toronto Press.

Waldram, J. B., Herring, D. A., \& Young, T. K. (2006). Aboriginal Health in Canada: Historical, Cultural, and Epidemiological Perspectives. Toronto: University of Toronto Press.

Weigel, R. H., \& Howes, P. W. (1985). Conceptions of Racial Prejudice: Symbolic Racism Reconsidered. Journal of Social Issues, 41, 117-138. http://dx.doi.org/10.1111/j.1540-4560.1985.tb01132.x

Williams, L. (2012). He Whanaungatērā: The Politics and Practice of an Indigenous and Intercultural Approach to Ecological Well-Being. In L. Williams, R. Roberts, \& A. McIntosh (Eds.), Radical Human Ecology: Intercultural and Indigenous Approaches (pp. 397-420). Farnham: Ashgate. 
Scientific Research Publishing (SCIRP) is one of the largest Open Access journal publishers. It is currently publishing more than 200 open access, online, peer-reviewed journals covering a wide range of academic disciplines. SCIRP serves the worldwide academic communities and contributes to the progress and application of science with its publication.

Other selected journals from SCIRP are listed as below. Submit your manuscript to us via either submit@scirp.org or Online Submission Portal.
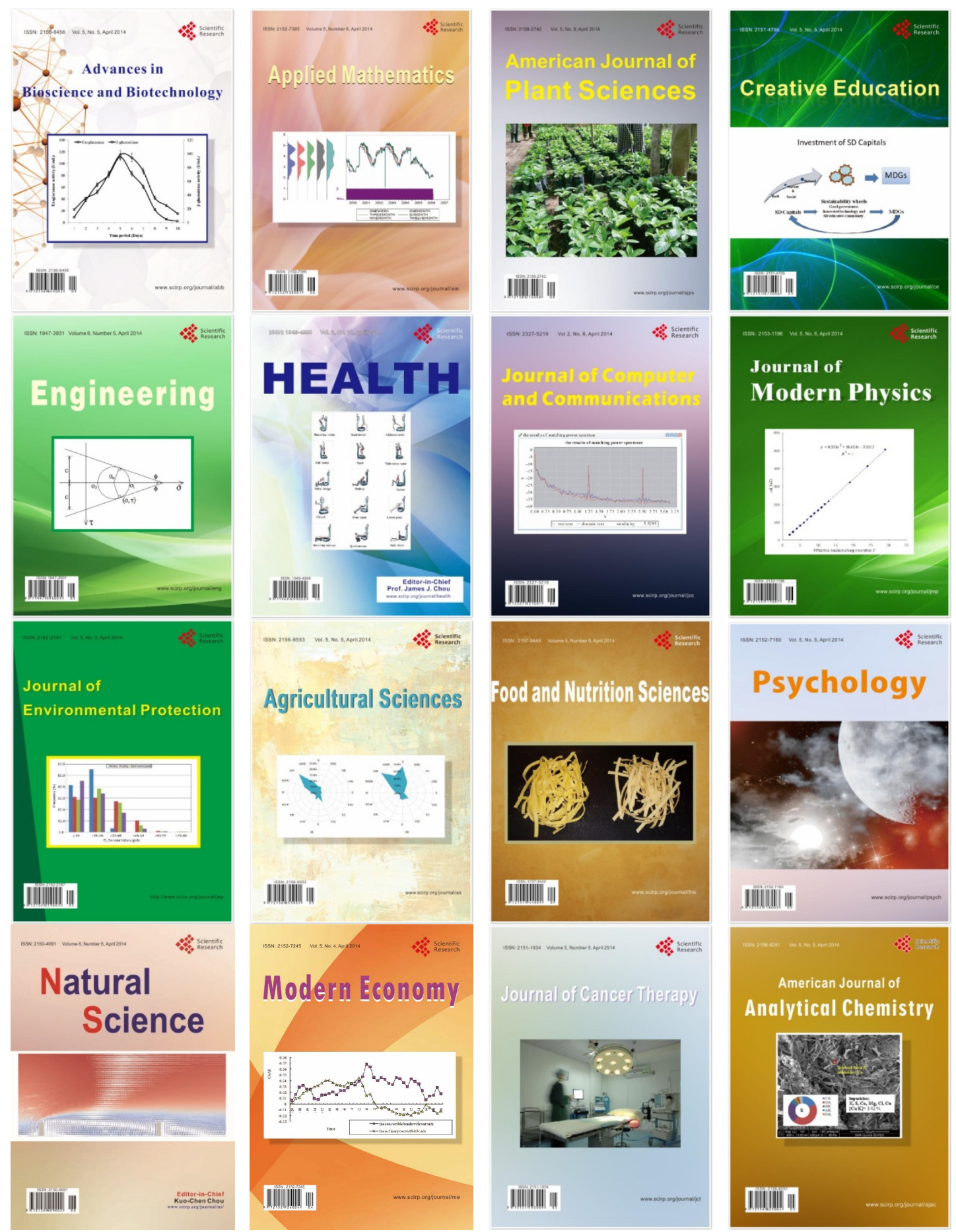